\title{
Processing of low carbon steel plate and hot strip-an overview
}

\author{
B K PANIGRAHI \\ R\&D Centre for Iron and Steel, Steel Authority of India Ltd., Ranchi 834 002, India
}

MS received 28 March 2001

\begin{abstract}
Soaking temperature, drafting schedule, finish rolling and coiling temperatures all play important roles in processing of low carbon plate and strip. They control the kinetics of various physical and metallurgical processes, viz. austenitization, recrystallization and precipitation behaviour. The final transformed microstructures depend upon these processes and their interaction with each other. In view of increasing cost of input materials, new processing techniques such as recrystallized controlled rolling and warm rolling have been developed for production of plates and thinner hot bands with very good deep drawability respectively. Besides hybrid computer modelling is used for production of strip products with tailor made properties. Although there have been few reviews on low carbon microalloyed steels in the past the present one deals with new developments.
\end{abstract}

Keywords. Microalloyed steel; thermomechanical processing; warm rolling; modelling of process parameters.

\section{Introduction}

Plate and hot strip occupy large share of steel products in the country. They have a range of yield strengths from 250 to $500 \mathrm{MPa}$ to suit different applications. These steels are produced with various alloying elements and processed suitably to obtain the desired yield strength and toughness. The hot processing of plate and strip consists of reheating of semis i.e. slabs, successive reduction of stock thickness in rolling mill, finishing the rolling at specific temperatures and additionally for hot strip accelerated water cooling on run-out table. Through these steps an attractive combination and range of yield strengths and impact properties can be developed starting from a single steel alloy. This has more relevance today than ever before due to increasing costs of alloying elements. The control that can be exercised at various stages of modern plate and hot strip mill enables achievement of a higher degree of consistency in mechanical properties and microstructure. Instigated by increased cost of downstream processing, significant advances were made in development of warm or ferrite rolling technology (Perry et al 2000; Tomitz and Kaspar 2000) that has direct impact in substituting cold rolled and annealed products for market segments where a much higher drawability and surface finish are less demanding. The computer simulation and process modelling have made production of tailor made properties in steel a stark reality not visualized previously (Siemens 2000). This paper is intended to outline various aspects of processing sequence, viz. soaking, finish rolling temperatures, coiling temperatures, drafting schedule and their impact on quality vis-a-vis mechanical properties of low carbon steel including microalloyed steel and advances that have been made in automation of hot strip processing lines. The microalloyed steels are high strength structural steels having minimum yield strength of about $350 \mathrm{MPa}$ and are alloyed with small per cent of niobium, vanadium or titanium (Panigrahi et al 1980). They are weldable and have very good strength to weight ratio, toughness, ductility and weldability. Their strength is controlled by various mechanisms, viz. solid solution strengthening, grain refinement, precipitation strengthening, dislocation strengthening and sub-structure strengthening (Pickering 1978).

\section{Effect of soaking temperature}

The soaking temperature is important because it can influence product yield and quality. The liquid steel is cast as ingot or slab. If the ingot soaking temperature and ingot residence time in soaking pit are very high presence of molten core in the ingot can adversely influence the quality and yield of semis. When the ingot soaking temperature is on lower side $\left(\sim 1280^{\circ} \mathrm{C}\right)$ a higher residence time in the soaking pit will facilitate complete solidification of ingot in the soaking pit prior to rolling (Ginzburg 1989) improving the yield and quality of product. Another important feature of soaking temperature is its influence on composition homogenization of semis. This is accomplished by reheating to pre-determined temperature. The changes that occur in various stages of reheating have been shown schematically in figure 1 for a low carbon steel. They are (a) increase of free carbon, (b) dissolution of cementite, (c) ferrite to austenite transformation, (d) austenite grain growth/coarsening and (e) dissolution of precipitates. On heating a low carbon steel some carbon is liberated up to $A c_{1}$. At $A c_{1}$ austenite starts 
nucleating. Two different nucleation sites are theoretically possible: ferrite/ferrite grain boundaries and ferrite/ cementite interface (Speich et al 1969). The austenite nucleation on the ferrite/cementite interface is thermodynamically encouraged by local carbon and manganese (Lenel and Honeycombe 1984). Presence of precipitates of microalloying elements would not inhibit austenite nucleation (Hirsch and Parker 1981). The austenite nucleus rapidly envelops the cementite particle which then

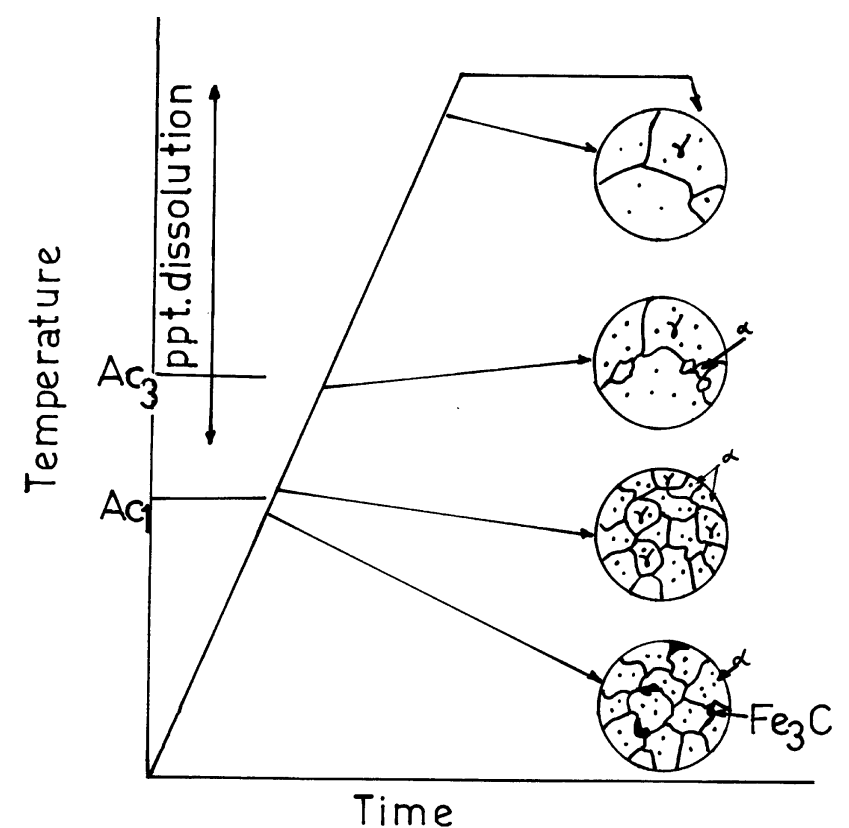

Figure 1. Schematic effect of reheating temperature on microstructure.

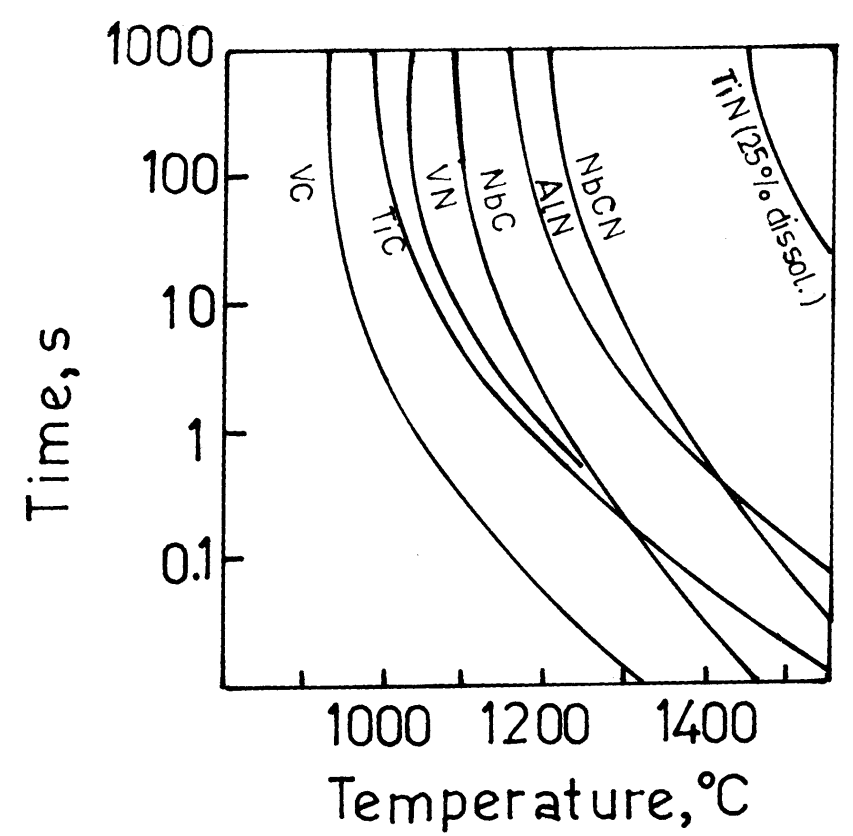

Figure 2. Dissolution kinetics of precipitates. dissolves completely enriching the austenite with its carbon. If $t$ is the time for $90 \%$ dissolution of cementite of radius $r$, then $t=10 r^{2} / D c$ (Hillert et al 1971), where $D c$ is diffusion coefficient of carbon in austenite. For $r=1 \mu \mathrm{m}, \quad D c=2.5 \times 10^{-7} \mathrm{~cm}^{2} / \mathrm{s}$ (with about $0.1 \% \mathrm{C}$ ) at $1000^{\circ} \mathrm{C}$ (Smith 1953), $t=1 / 4 s$. However, as it is well known that cementite can be enriched by substitutional solute elements, $\mathrm{Mn}, \mathrm{Mo}, \mathrm{Cr}$ etc the cementite tended to be $(\mathrm{Fe}, \mathrm{Mn}, \mathrm{Cr}, \mathrm{Mo})_{3} \mathrm{C}$ instead of $\mathrm{Fe}_{3} \mathrm{C}$ (Thomson and Bhadeshia 1994; Thomson and Miller 1998). Enriched cementite becomes less soluble because of high binding energies of substitutional elements in the cementite (Speich et al 1981). Therefore, a decrease in transformation kinetics of cementite into austenite is observed.

Similarly dissolution of other precipitates, particularly $\mathrm{AlN}, \mathrm{VC}, \mathrm{VN}, \mathrm{Nb}(\mathrm{CN}), \mathrm{TiN}$, is also time and temperature dependent (figure 2) (Easterling 1992). This should be taken into consideration while adjusting the reheating temperatures. Undissolved precipitates, particularly TiN and $\mathrm{Nb}(\mathrm{CN})$, which have solution temperatures $>1250^{\circ} \mathrm{C}$ and $\sim 1150^{\circ} \mathrm{C}$, respectively help to inhibit austenite grain coarsening by pinning austenite grain boundaries (Cuddy 1985). Greatest effect is observed for TiN (figure 3). Dissolution temperatures of $\mathrm{Nb}(\mathrm{CN})$ in steels of different carbon and niobium levels have been given in table 1 (Lamberigts and Greday 1974). The data show that the

Table 1. Solution temperatures $\left({ }^{\circ} \mathrm{C}\right)$ of $\mathrm{Nb}(\mathrm{CN})$ in austenite.

\begin{tabular}{lrrrrrr}
\hline & \multicolumn{6}{c}{$\% \mathrm{Nb}$} \\
\cline { 2 - 7 }$\% \mathrm{C}$ & $0 \cdot 01$ & 0.02 & 0.03 & 0.04 & 0.05 & 0.06 \\
\hline $0 \cdot 05$ & 971 & 1021 & 1050 & 1074 & 1092 & 1107 \\
$0 \cdot 10$ & 1012 & 1066 & 1097 & 1122 & 1142 & 1157 \\
$0 \cdot 15$ & 1038 & 1092 & 1126 & 1152 & 1172 & 1189 \\
$0 \cdot 18$ & 1049 & 1105 & 1141 & 1166 & 1187 & 1205 \\
$0 \cdot 25$ & 1069 & 1127 & 1165 & 1190 & 1212 & 1230 \\
\hline
\end{tabular}

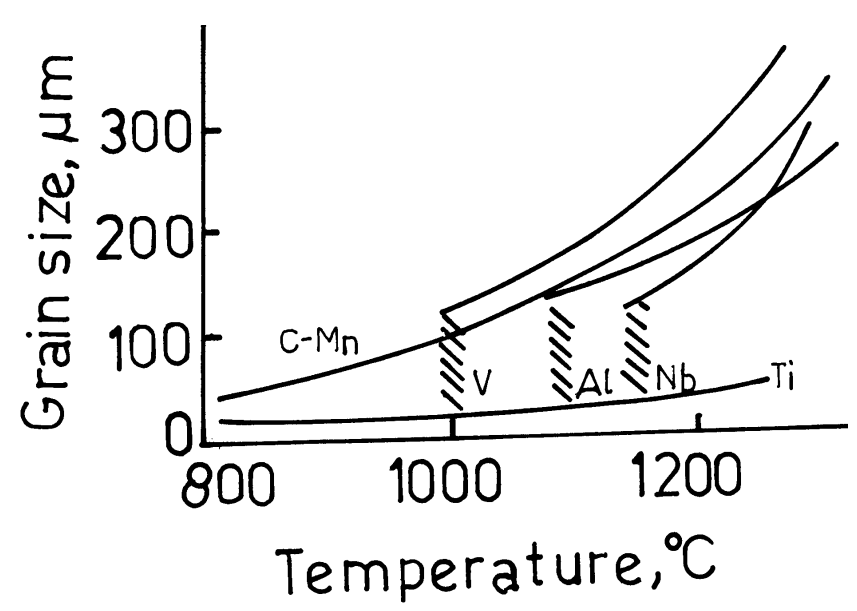

Figure 3. Effect of reheating temperatures on austenite grain size. 
undissolved precipitates are not available in a low carbon steel above $1150^{\circ} \mathrm{C}$ for pinning austenite grain boundaries.

\section{Effect of drafting schedule}

Drafting schedule is a set of reduction sequence by which slabs are converted to plate or strip. Drafting schedule influences the final product properties to a large extent due to its influence on recrystallization and precipitation kinetics. Prior knowledge of hot strength (mean flow stress) of austenite facilitates formulation of drafting schedules of slabs and setting the mill screw down to obtain a specific gauge, and to avoid mill tripping.

When the austenite is deformed its dislocation density is increased. Dynamic or static recovery follows with development of sub-grains within austenite (McQueen and Jonas 1973). Alloying elements can increase the hot strength of austenite (figure 4) as they impede the motion
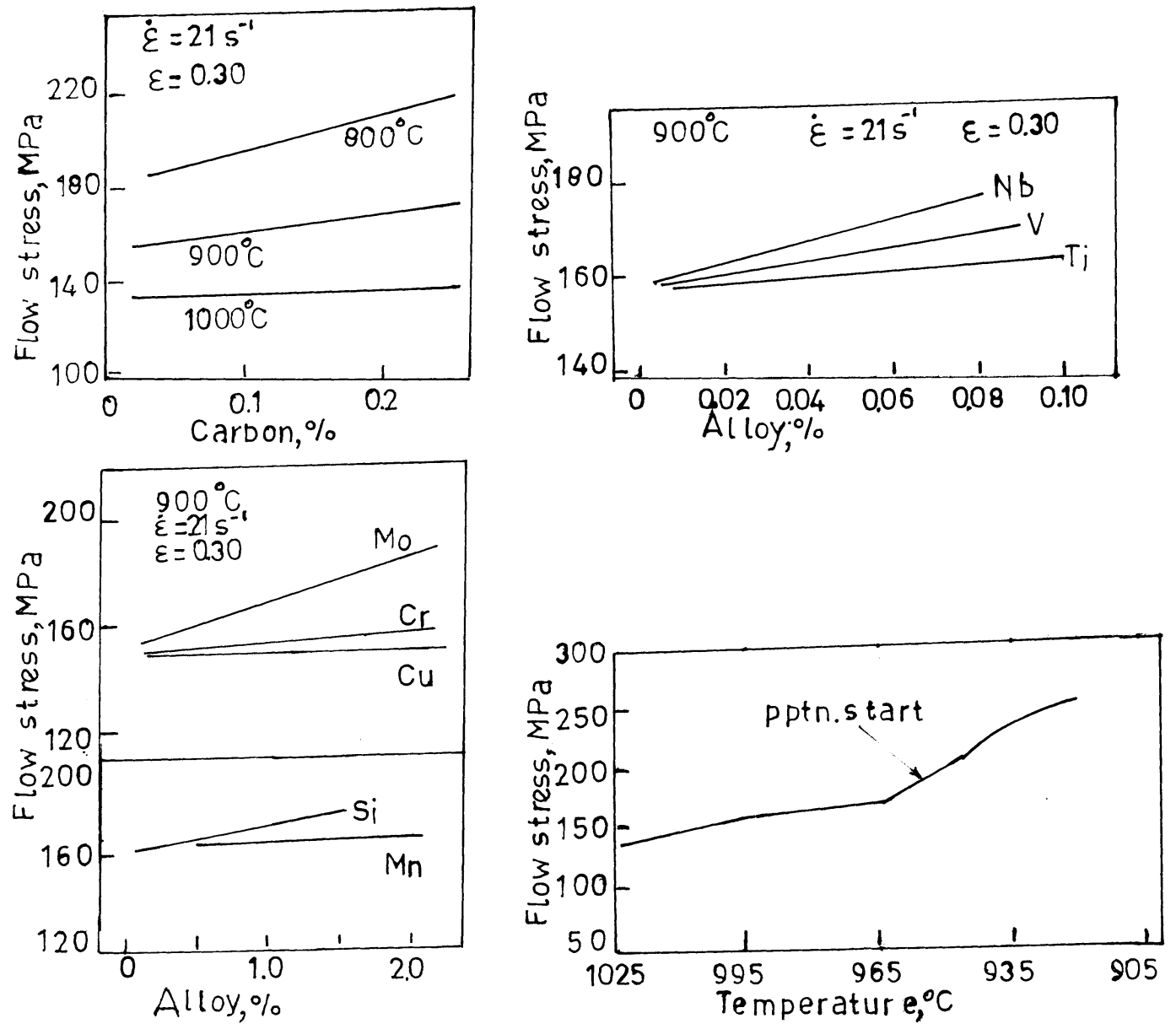

Figure 4. Effect of alloying elements and precipitates on hot strength of austenite.

Table 2. Influence of size factor on hot strength of austenite.

\begin{tabular}{|c|c|c|c|c|c|}
\hline \multirow[b]{2}{*}{ Element } & \multirow{2}{*}{$\begin{array}{c}\text { Atomic diameter at } \\
1000^{\circ} \mathrm{C} \\
(\AA)\end{array}$} & \multirow{2}{*}{$\begin{array}{l}\% \text { difference in size } \\
\text { relative to iron }\end{array}$} & \multicolumn{3}{|c|}{$\begin{array}{l}\% \text { change in hot strength } \\
\text { for } 1 \% \text { element }\end{array}$} \\
\hline & & & $1000^{\circ} \mathrm{C}$ & $1100^{\circ} \mathrm{C}$ & $1200^{\circ} \mathrm{C}$ \\
\hline $\mathrm{Si}$ & $2 \cdot 36$ & $-8 \cdot 5$ & $+8 \cdot 3$ & $+2 \cdot 4$ & $-3 \cdot 6$ \\
\hline $\mathrm{Ni}$ & $2 \cdot 48$ & $-3 \cdot 9$ & $-0 \cdot 1$ & $-0 \cdot 2$ & $-0 \cdot 3$ \\
\hline $\mathrm{Cr}$ & $2 \cdot 51$ & $-2 \cdot 7$ & $+2 \cdot 1$ & $+1 \cdot 6$ & $+1 \cdot 1$ \\
\hline $\mathrm{Fe}$ & $2 \cdot 58$ & - & - & - & - \\
\hline $\mathrm{Mn}$ & $2 \cdot 70$ & $+4 \cdot 7$ & $+5 \cdot 3$ & $+4 \cdot 0$ & $+2 \cdot 8$ \\
\hline Mo & $2 \cdot 74$ & $+6 \cdot 2$ & $+13 \cdot 0$ & $+10 \cdot 5$ & +7.9 \\
\hline $\mathrm{Al}$ & $2 \cdot 95$ & $+15 \cdot 9$ & $+16 \cdot 3$ & $+13 \cdot 6$ & $+9 \cdot 5$ \\
\hline
\end{tabular}


of dislocations (Zidek et al 1969; Tamura et al 1988). The large size difference with respect to iron atoms leads to maximum increase in hot strength (table 2) (McQueen and Jonas 1973) as this causes localized distortion. Data also reveal that significant increase in hot strength occurs when drafting is given at lower temperature. The interstitial carbon has negligible effect on hot strength above $900^{\circ} \mathrm{C}$ due to its high diffusion rate. Precipitates in fine distribution also increase the hot strength of austenite through their interaction with dislocations as shown in figure 4 for niobium carbonitride precipitates in a $0.06 \% \mathrm{C}, 1.25 \% \mathrm{Mn}, 0.32 \% \mathrm{Si}, 0.075 \% \mathrm{Nb}, 0.024 \% \mathrm{Ti}$, $0.035 \%$ Al steel (Siciliano and Jonas 2000).

Various formulas are available in the literature for calculation of hot strength of austenite which give a fairly good indication of hot strength of austenite at the rolling temperatures. Two formulas for plate (McTegart and Gattins 1976) and strip (Siciliano and Jonas 2000) which can be used for different levels of strain rate are given below:

$$
k_{\mathrm{p}}=A 0+r^{n}\left(A 1+A 2 \ln \dot{\varepsilon}+\frac{A 3}{T / 1000}\right),
$$

where, $k_{\mathrm{p}}$ is the hot strength of austenite, $r$ the reduction ratio $(0 \cdot 1-0 \cdot 4), n$ the work hardening exponent $(\sim 0 \cdot 2)$, $\dot{\varepsilon}$ the true strain rate in rolling $\left(2-20 \mathrm{~s}^{-1}\right), T$ the rolling temperature $\left({ }^{\circ} \mathrm{K}\right)$. The values of $A 0, A 1, A 2$ and $A 3$ are given in table 3 (McQueen and Jonas 1973). Another

Table 3. Mean yield stress coefficients.

\begin{tabular}{lrrcc}
\hline Steel & \multicolumn{1}{c}{ A0 } & A1 & A2 & A3 \\
\hline Mild steel & 0.49 & 516.6 & 21.3 & $-357 \cdot 2$ \\
Low alloy & -1.78 & 564.6 & 19.9 & -368.5 \\
Stainless & 1.40 & 745.3 & 22.2 & -485.5 \\
\hline
\end{tabular}

formula for calculating mean flow stress (MFS) of C-Mn and microalloyed hot strip is

$$
\begin{aligned}
& \text { MFS }= \\
& \left\{\operatorname { e x p } \left(0 \cdot 126-1 \cdot 75 \mathrm{C}+0 \cdot 594 \mathrm{C}^{2}+\left(\frac{2851+2968 \mathrm{C}-1120 \mathrm{C}^{2}}{T}\right)\right.\right. \\
& \left.\left.\quad \varepsilon^{0 \cdot 21} \dot{\varepsilon}^{0.13}\right)(0 \cdot 768+0 \cdot 51 \mathrm{Nb}+0 \cdot 137 \mathrm{Mn}+4 \cdot 217 \mathrm{Ti})\right\} \\
& \quad\left(1-X_{\mathrm{d}}\right)+K \sigma_{\mathrm{ss}} X_{\mathrm{d}}
\end{aligned}
$$

where, $T$ is the rolling temperature $\left({ }^{\circ} \mathrm{K}\right), \varepsilon$ the true strain, $\dot{\varepsilon}$ the true strain rate $\left(\mathrm{s}^{-1}\right), X_{\mathrm{d}}$ the softening due to dynamic recrystallization, $\sigma_{\mathrm{ss}}$ the steady state stress, $K$, a parameter that converts flow stress to mean flow stress $=1 \cdot 14$.

\subsection{Restoration processes}

Restoration processes, occurring as austenite is deformed over a range of temperatures, have important bearing on evolution of microstructures. In commercial plate and strip products dynamic recovery, static recovery and static recrystallization are important restoration processes (McTegart and Gattins 1976). Thermodynamically when a metal is deformed it is at a higher energy level and is in a non-equilibrium state. It will strive to return to equilibrium, if possible, by lowering its free energy by decreasing density of defects through a set of restoration processes, viz. dynamic recovery, static recovery and static recrystallization, which is shown schematically in figure 5 (Hensel and Lehnert 1973). Assuming dislocation annihilation is the driving force $\left(F_{\mathrm{R}}\right)$ for recovery and

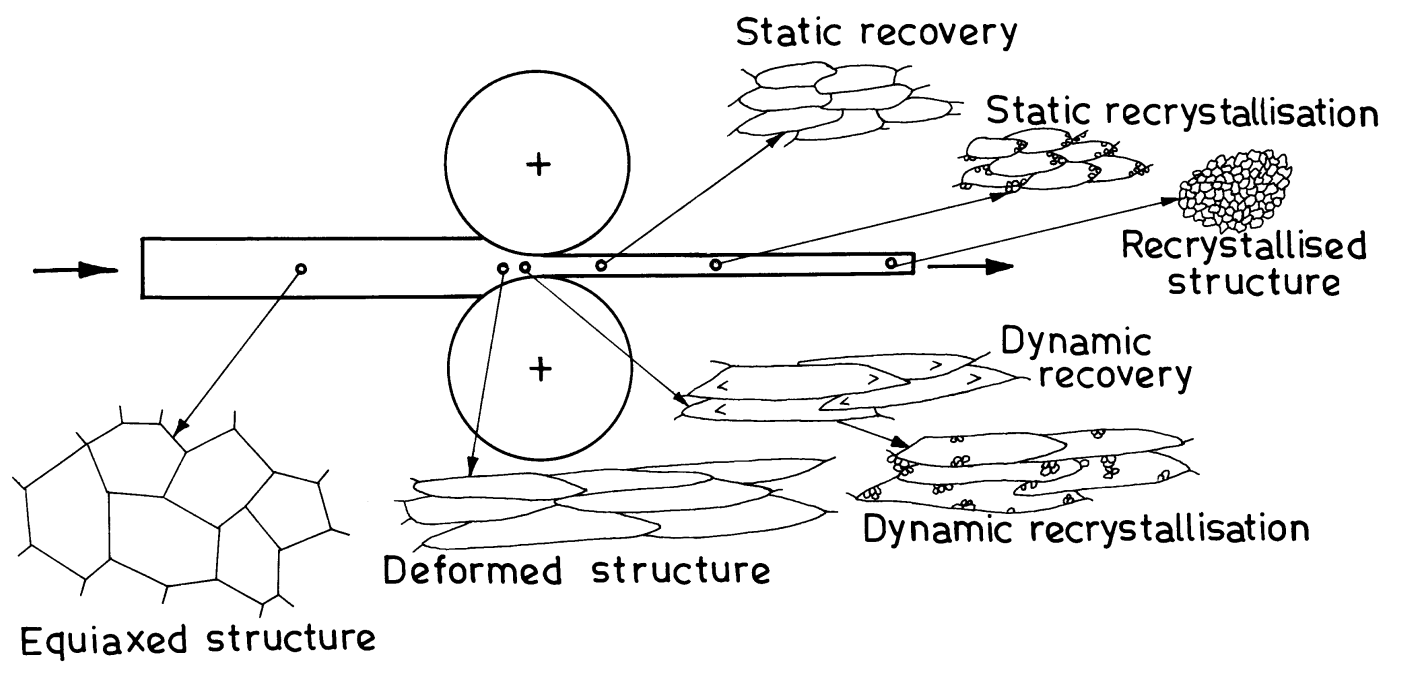

Figure 5. Schematic of restoration processes. 
recrystallization, then the driving force for static recrystallization may be estimated from the reduction of stored energy per unit volume resulting from the traverse of the recrystallization front (Hansen et al 1980). This gives

$$
F_{\mathrm{R}}=\frac{\mu b^{2} \Delta \rho}{2},
$$

where, $\mu$ is the shear modulus $=7 \times 10^{4} \mathrm{MPa}, b$ the burgers vector $=2.5 \times 10^{-10} \mathrm{~m}$ and $\Delta \rho$ the change in dislocation density associated with migration of recrystallization front into deformed region $\sim 2 \times 10^{14}$ lines $/ \mathrm{m}^{2}$.

For each material there is a static recrystallization stop temperature (Borato et al 1988) given by

$$
\begin{gathered}
t_{\mathrm{nr}}\left({ }^{\circ} \mathrm{C}\right)=887+464 \mathrm{C}+(6645 \mathrm{Nb}-664 \sqrt{\mathrm{Nb}})+ \\
(732 \mathrm{~V}-230 \sqrt{\mathrm{V}})+890 \mathrm{Ti}+363 \mathrm{Al}-357 \mathrm{Si},
\end{gathered}
$$

where the elements are in wt.\%. If the deformation temperature lies above $t_{\mathrm{nr}}$ it will produce an equiaxed

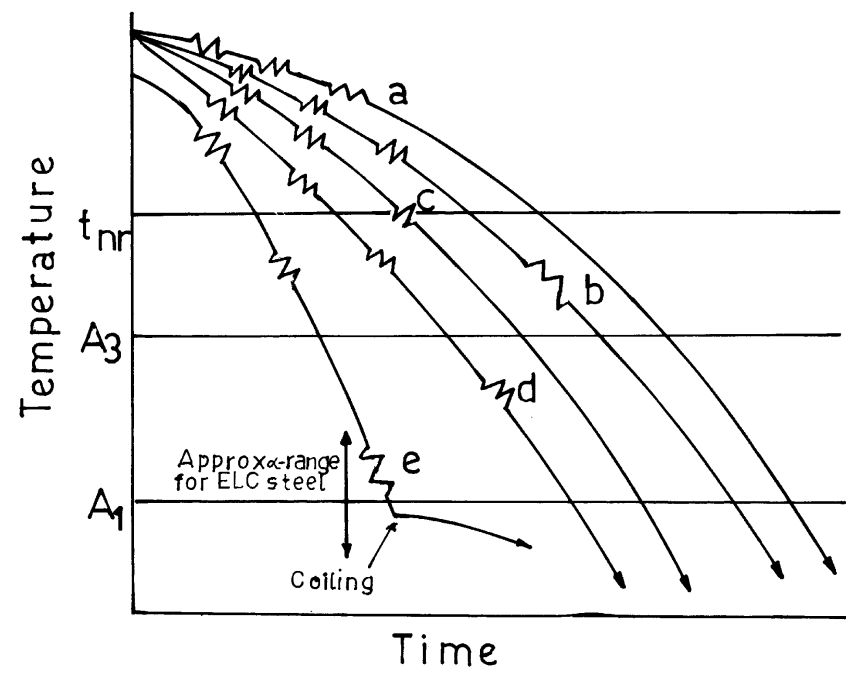

Figure 6. Schematic of rolling schedules for low carbon and ELC steels. austenite structure by static recrystallization (figure 6). Below $t_{\mathrm{nr}}$, recrystallization becomes sluggish. Alloying elements and precipitates retard the static recrystallization by drag effect and pinning effect on austenite grain boundaries, respectively (Meyer et al 1971). The maximum retardation of recrystallization occurs if conditions are favourable for strain induced precipitation (figure 7) (LeBon and Rofes Vernis 1976; Ouchi and Sampei 1976). In $\mathrm{Nb}$-bearing steel, the temperature for maximum strain induced precipitation is $\sim 900^{\circ} \mathrm{C}$ (figure 7). Strain induced precipitates are very fine $(3-7 \mathrm{~nm})$. They have little contribution on yield strength since they get coarsened at higher temperatures of hot working. Besides dynamic recrystallization can occur in hot strip mill at high strain and temperature generally in the roll gap of last two stands of finishing mill by strain accumulation (Robiller and Meyer 1980). The critical strain for dynamic recrystallization (Kwon et al 1998) is:

$$
\varepsilon_{\mathrm{c}}=8.03 \times 10^{-4} D o^{0.167} \varepsilon^{-0.071} Z^{0.177},
$$

where, $D o$ is the initial grain size, $\varepsilon$ the true strain, $Z$ the Zener-Holomon parameter $=\dot{\varepsilon} \exp (312000 / R T), \dot{\varepsilon}$ the true strain rate, $R$ the gas constant, $T$ the temperature in ${ }^{\circ} \mathrm{K}$. When the accumulated strain reaches the value of $\varepsilon_{\mathrm{c}}$ dynamic recrystallization occurs in the roll gap.

\section{Effect of finishing rolling temperatures}

The finishing rolling temperatures (FRT) for plates and hot strip influence the ferrite grain size and mechanical properties. Depending upon the chemistry and final mechanical properties, FRT is set. There are five possibilities of FRT (figure 6): (a) FRT in recrystallized austenite region (recrystallized controlled rolling), (b) FRT in unrecrystallized austenite region, (c) FRT in border of (a) and (b), (d) FRT in austenite - ferrite region and (e) FRT in ferrite region.

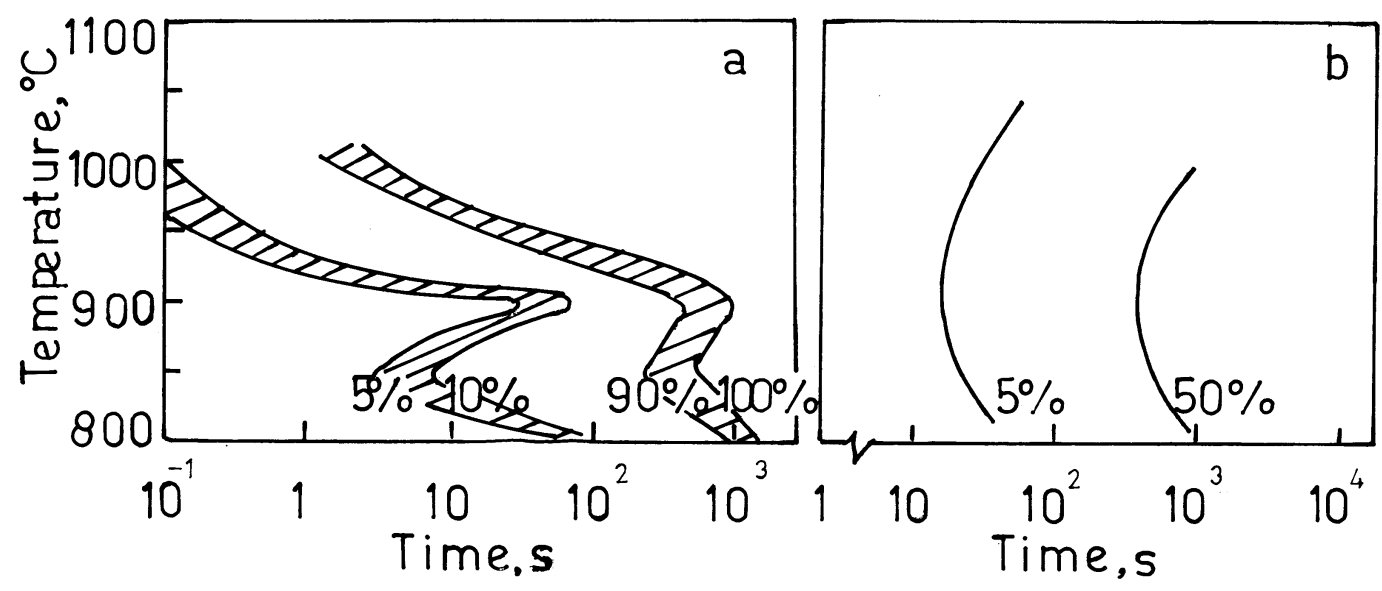

Figure 7. Kinetics of recrystallization (a) and precipitation (b) in Nb-microalloyed steel. 
(a) When FRT is in recrystallized austenite region which is known as recrystallized controlled rolling (Bleck et al 1990), a fully recrystallized austenite structure is obtained which on transformation produces a recrystallized ferrite microstructure. Ferrite nucleates on austenite grain boundaries. The grain size of transformed ferrite $\left(d_{\alpha}\right)$ will depend upon the recrystallized austenite grain size $\left(d_{\gamma}\right)$ and cooling rate from FRT. If $S_{\mathrm{V}}$ is the effective grain boundary area per unit volume, $S_{\mathrm{V}} \sim 1 / 0.5 d_{\gamma}$ (Underwood 1970) and

$$
d_{\alpha}=3 \cdot 75+0 \cdot 18 d_{\gamma}+1 \cdot 4(\mathrm{~d} T / \mathrm{d} t)^{-1 / 2},
$$

$\mathrm{d} T / \mathrm{d} t$ is the average cooling rate between $750-550^{\circ} \mathrm{C}$ in ${ }^{\circ} \mathrm{C} / \mathrm{s}, d_{\alpha}$ the transformed ferrite grain size in $\mu \mathrm{m}$ and $d_{\gamma}$ the recrystallized austenite grain size in $\mu \mathrm{m}$ prior to cooling.

Through recrystallized controlled rolling a post-rolling normalizing operation can in most cases be eliminated, saving energy costs and increasing productivity. This is schematically shown for a plate rolling in figure 8 (top curve).

(b) If FRT is in unrecrystallized austenite (figure 8, middle curve) region, elongated austenite structure with deformation bands and twins will be produced in microalloyed steel (DeArdo 1984). Deformation bands nucleate on inhomogeneities which block dislocations on several adjacent slip lines causing the lateral growth of the band (Frank and Stroh 1952). In this case ferrite nucleates not only on the austenite grain boundaries but also on deformation bands and twins (Inagaki 1983; Tanaka 1984; Panigrahi et al 1984). The deformation bands and twins are observed in microalloyed steels when reduction per pass is above $20 \%$ in the unrecrystallized austenite region (figure 9) (Panigrahi 1981). In this case $S_{\mathrm{V}}$ would contain two terms, $S_{\mathrm{V}}=S_{\mathrm{V}}^{\mathrm{gb}}+S_{\mathrm{V}}^{\mathrm{db}+\mathrm{tw}}$, where $S_{\mathrm{V}}^{\mathrm{gb}}$ is grain boundary area per unit volume, $S_{\mathrm{V}}^{\mathrm{db}+\mathrm{tw}}$ is surface area of deformation

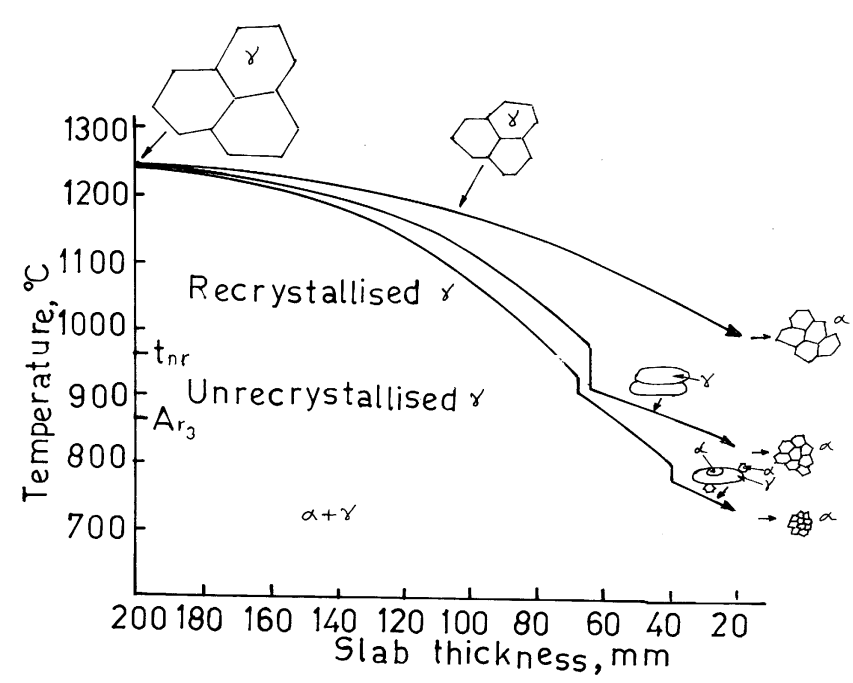

Figure 8. Drafting schedule for Nb-microalloyed plate. bands and twins. The transformed ferrite grains will be finer due to nucleation of ferrite on austenite grain boundaries, deformation bands and twins (figure 9) (Panigrahi 1981).

(c) When FRT is in the border of recrystallized and unrecrystallized austenite regions (figure 6) and per cent reduction is low, it can lead to mixed ferrite grain sizes (Jones and Rothwell 1968). This is due to inhomogeneous deformation of austenite grains (LeBon and Rofes Vernis 1976). A coarser austenite at intermediate stage of deformation $\sim 1050^{\circ} \mathrm{C}$, can also give mixed ferrite grains if not deformed sufficiently thereafter ( about $50 \%$ reduction in thickness below $\left.1050^{\circ} \mathrm{C}\right)$. Mixed grains result in poor impact toughness (Tanaka 1981).

(d) When FRT is in the two-phase $(\gamma+\alpha)$ region (figure 8 , bottom curve), a structure of deformed ferrite (which may recover or recrystallize), soft ferrite (i.e. recrystallized ferrite) and pearlite is formed (Tanaka 1981). This is schematically shown in figure 10. It has been presumed that austenite has recrystallized to an equiaxed grain structure prior to finish rolling in the two-phase region. As soon as the temperature drops below $\mathrm{Ar}_{3}$ temperature of the steel, ferrite nucleates on the austenite grain boundaries. Deformation in the two-phase region strain hardens austenite and newly formed ferrite grains. Under the influence of temperature, recovery process sets in, and austenite and ferrite both develop sub-structures (Dunne et al 1991). New ferrite grains nucleate on deformed austenite grain boundaries and also within austenite grains on dislocations (Priestner and de Los Rios 1976). The strain hardened ferrite can recrystallize to finer ferrite grains or remain in recovered state or unrecovered state depending upon the temperature, per cent reduction and alloying elements present in the steel. The precipitates of microalloying elements stabilize the sub-structure delaying recrystallization. The growth of newly formed ferrite on

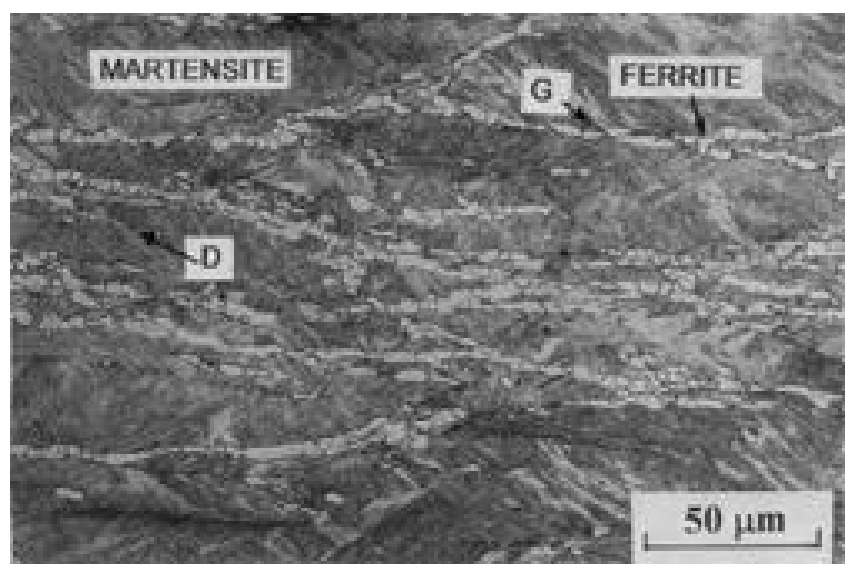

Figure 9. Microstructure showing ferrite nucleation sites in $\mathrm{Nb}+\mathrm{V}$ microalloyed steel. Samples were finish rolled in the unrecrystallized austenite region, quenched in iced brine, polished and etched with $2 \%$ nital (G: austenite grain boundary, D: deformation band). 
austenite grain boundaries will be inhibited by sub-grain boundary walls. When the temperature drops below $\mathrm{Ar}_{1}$ remaining austenite transforms to pearlite. Thus a structure of fine soft ferrite, recovered ferrite and possibly some hardened ferrite and pearlite will form at room temperature. This microstructure produces highest strength but introduces various degrees of yield stress anisotropy due to development of $<110>/ /$ RD texture (Bramfitt and Marder 1973). Besides through thickness embrittlement can also occur due to development of $\langle 100>/$ /ND texture (Tanaka 1981). The toughness will vary depending upon the extent of recovery and recrystallization. The presence of recrystallized fine ferrite will increase toughness due to numerous high angle grain boundaries. Presence of

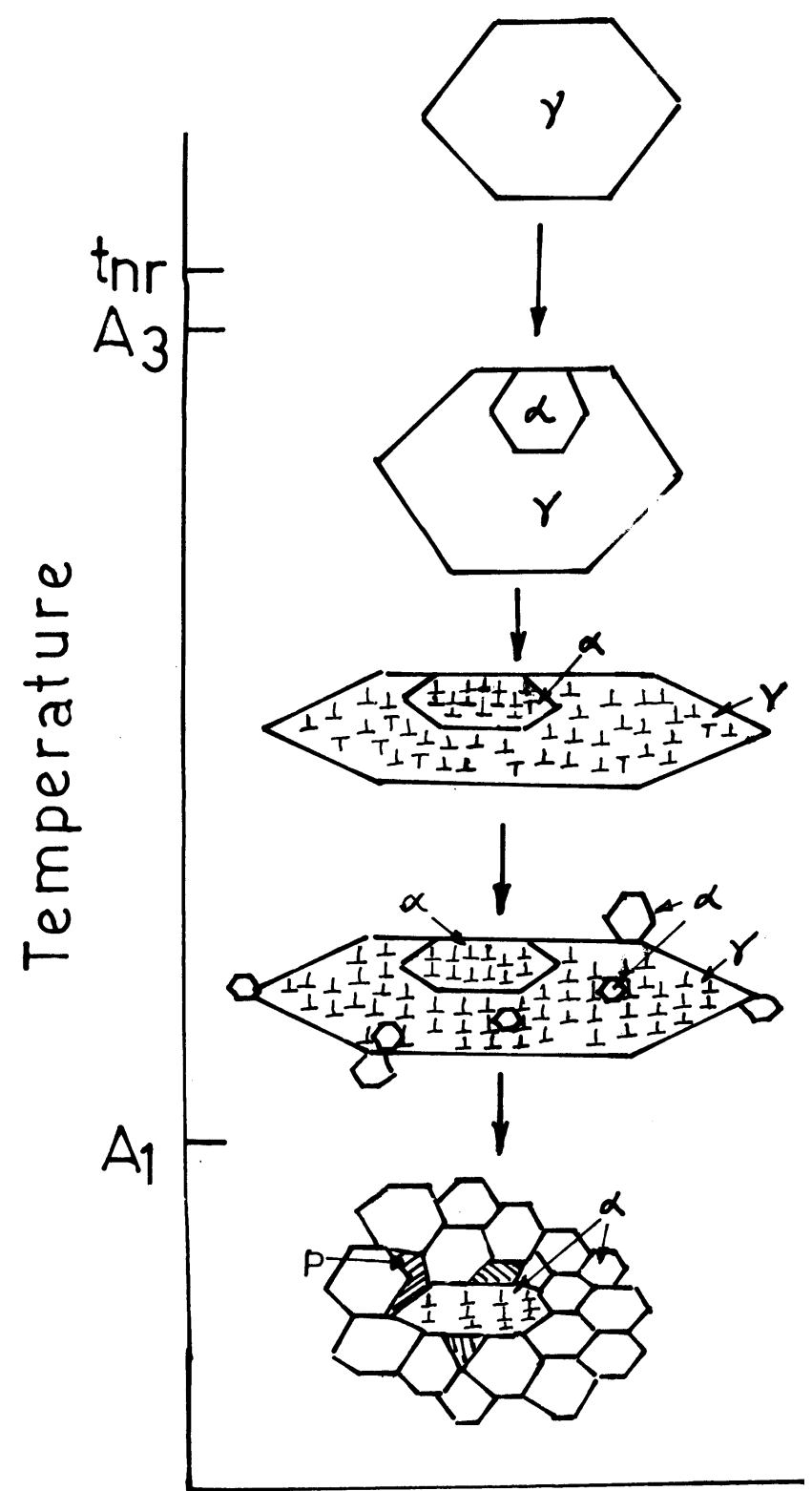

Figure 10. Schematic of ferrite nucleation in two-phase rolling of microalloyed steel ( $\mathrm{P}$, pearlite). recovered ferrite has no adverse effects on the toughness whereas presence of hardened ferrite will lower the toughness (Tanaka 1984).

(e) Finish rolling in ferrite phase is known as ferritic rolling or warm rolling (Perry et al 2000; Tomitz and Kaspar 2000). It is mainly used for extra low carbon $(\sim 0.01 \%)$ steels and interstitial free steels (Hoile 2000). An interstitial free steel is a steel with extremely low carbon $(30 \mathrm{ppm})$ and low nitrogen $(30 \mathrm{ppm})$ to which $\mathrm{Nb} / \mathrm{Ti}$ can be added. Warm rolling has several advantages. The ferritic region in extra low carbon (ELC) steel extends from about $600-800^{\circ} \mathrm{C}$ (figure 11) (Barnet and Jonas 1999). The finishing temperature lies within this range. The transformation from austenite to ferrite causes drop in rolling load (figure 12) (Barnet and Jonas 1999). Other advantages are increased furnace throughputs, low energy consumption, less scale loss and damage to slabs, less roll wear, less run-out table water consumption etc. The product exhibits low yield stress, high elongation and good normal anisotropy. For these properties an important requirement is full recrystallization during coiling. A much lower coiling temperature gives incomplete recrystallization and harder hot strip with lower $\bar{r}$. A lower slab reheating temperature $\sim 1100^{\circ} \mathrm{C}$ ensures high $\bar{r}$ value by dissolving only a smaller proportion of pre-existing AIN precipitates (Jabs 1995) without affecting much the recrystallization process in coiler. Typically $\bar{r}$ value of 1.5 is not uncommon. Thinner hot band $(1 \mathrm{~mm})$ can be produced by ferritic rolling. This way downstream cold rolling and annealing can be eliminated in application where surface finish and too high $\bar{r}$ value are less demanding. Typical composition, mechanical properties and microstructural features of steel subjected to warm rolling are given in table 4 (Harlet et al 1993).

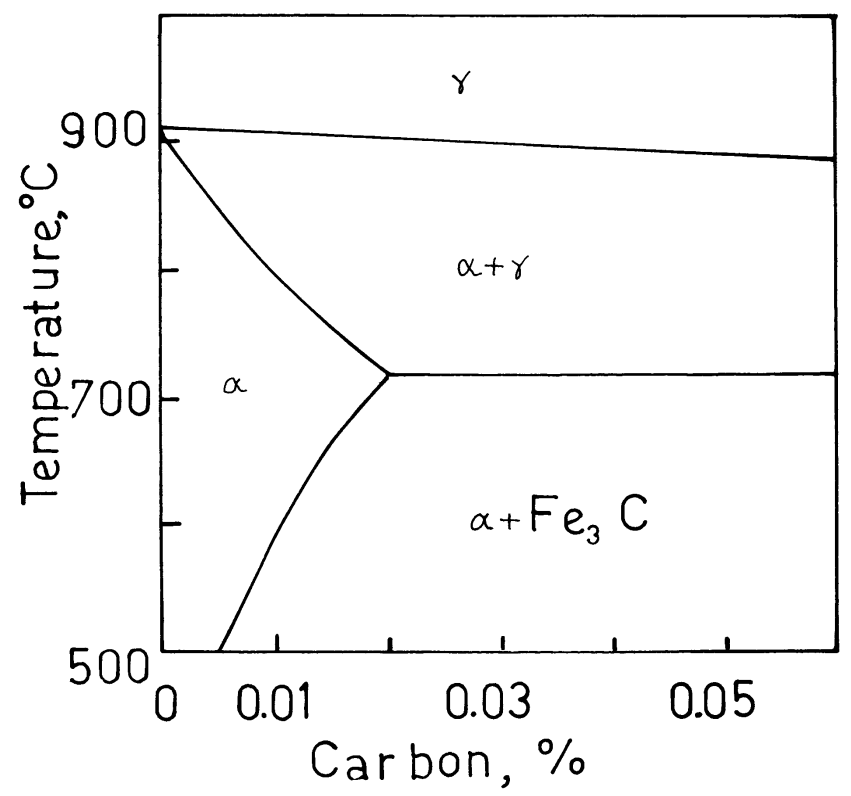

Figure 11. Carbon content and temperature range for warm rolling. 


\section{Effect of coiling temperatures}

Coiling temperatures (CT) of hot strip influence ferrite grain size and morphology, interlamellar spacings of pearlite, pearlite lamella thickness, grain boundary cementite morphology, grain boundary cementite film thickness and precipitate morphology. By varying finish rolling temperatures and run-out table cooling rates coiling temperature can be controlled. There are two possibilities: (i) low coiling temperature and (ii) high coiling temperature.

(i) A low coiling temperature can range from about 650 $550^{\circ} \mathrm{C}$. One of the objectives of hot strip rolling is to avoid a mixed grain structure. To avoid mixed grain structure austenite should have acquired adequate stored energy when it leaves the finishing mill (McTegart and Gattins 1976). Figure 13 schematically shows the austenite structure as it emerges from the finishing mill. The elongated austenite grain morphology can be preserved by suppressing recrystallization on run-out table by water cooling particularly for $\mathrm{Nb}$-microalloyed steel, though recovery can occur on the run-out table under the influence of temperature before the strip enters the coiler at lower temperature. In coiler, ferrite nucleates on austenite grain boundaries and within austenite grains on defects due to thermodynamic super cooling (DeArdo 1984). This should lead to an equiaxed fine ferrite grain size on transformation with a fine grain boundary cementite. A faster cooling associated with much lower coiling temperature $\left(\sim 550^{\circ} \mathrm{C}\right)$ facilitates $\mathrm{Al}$ and $\mathrm{N}$ to remain in solution

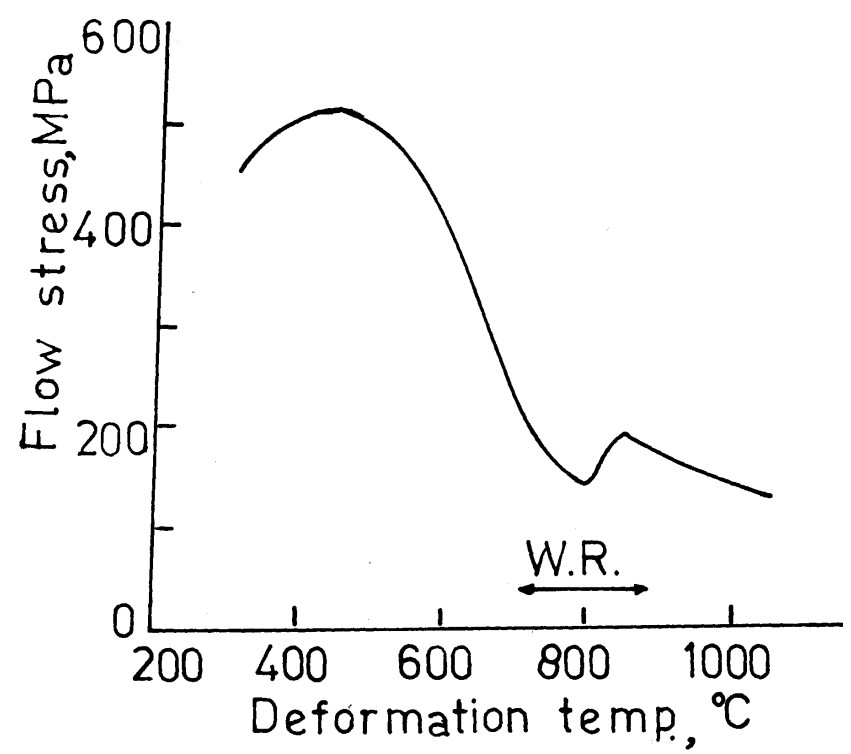

Figure 12. Effect of deformation temperature on flow stress of extra low carbon (ELC) steel.

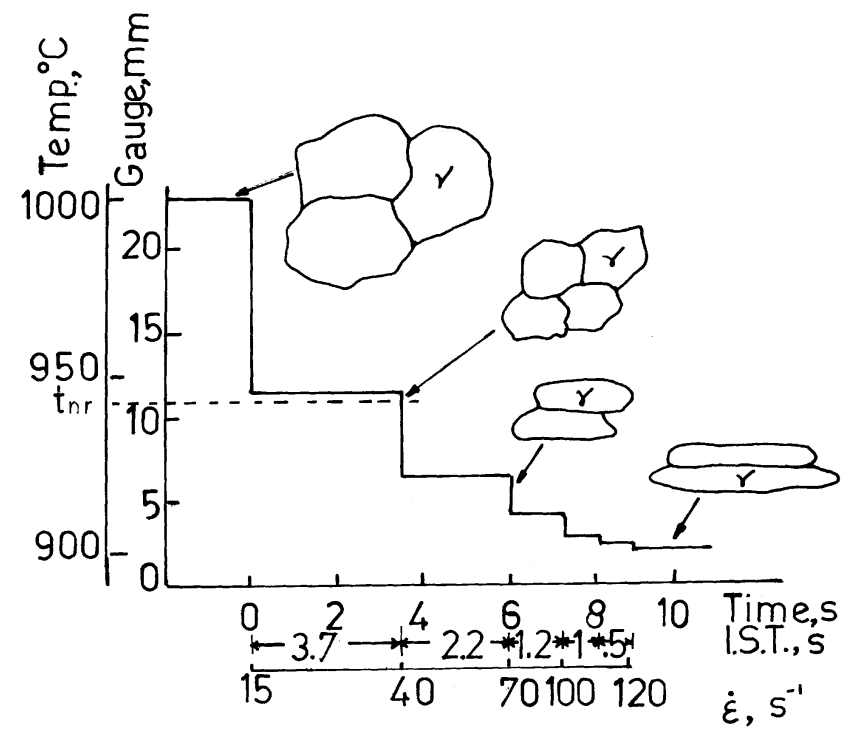

Figure 13. Drafting schedule for hot strip (IST, inter stand time; $\dot{\varepsilon}:$ strain rate).

Table 4. Chemistry (wt.\%), process parameters and properties of warm rolled steel.

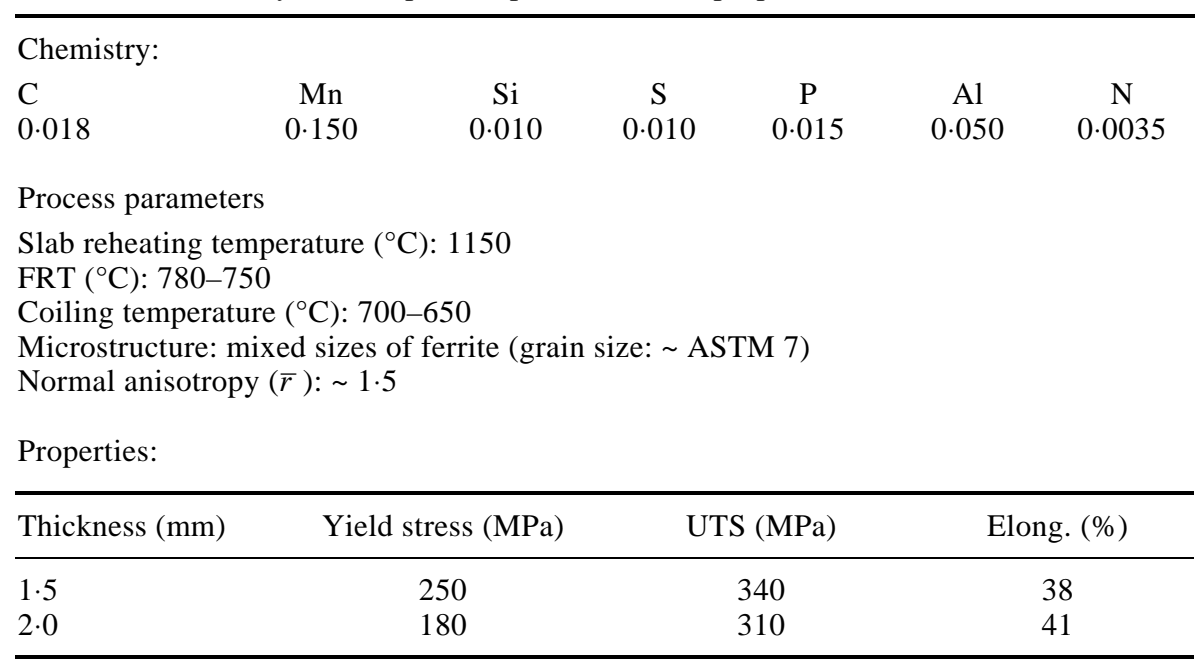


(Wilson and Gladman 1988) in hot strip besides forming extremely fine ferrite grains, finer grain boundary carbides (figure 14a) and low volume fraction of precipitates of microalloyed carbonitrides. Grain size and carbonitride precipitate are less finer when coiling temperature is around $690^{\circ} \mathrm{C}$ (figure 14b). In a low carbon steel (C $\sim 0.04 \%)$ with $\mathrm{Nb}$, a too fast run-out table cooling is not required since due to presence of microalloyed carbonitrides the austenite recrystallization becomes sluggish (LeBon and Rofes Vernis 1976) and the strip can still enter the coiler in elongated austenite morphology. This will ensure finer ferrite grain size on transformation and adequate precipitation of fine niobium carbonitrides in hot strip (Meyer and deBoer 1977).

(ii) A high coiling temperature can be well above $A_{1}$. This is demanded for some grades of low carbon steel requiring cold rolling and batch annealing (Van Cauter et al 2000). When coiling temperature is above $A_{1}$, ferrite and austenite coexist prior to coiling in the coiler besides aluminium and nitrogen are present in the hot strip as AlN precipitates. The austenite which has a higher solubility of carbon becomes richer in carbon and after the transformation to ferrite coarse cementite clusters appear on the grain boundaries. This has been schematically shown in (a)

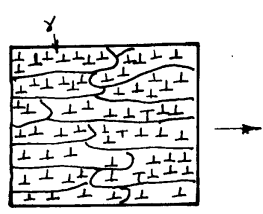

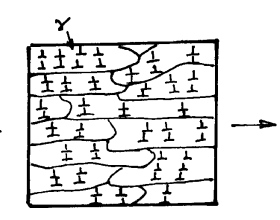

ROT

(b)

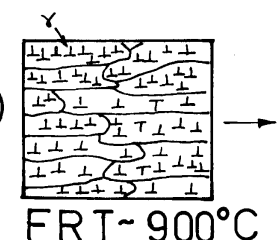

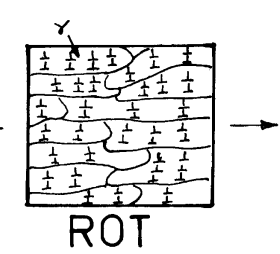
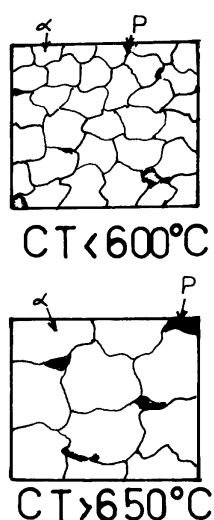

Figure 14. Influence of coiling temperature on structure of hot strip (CT: low) (P, cementite).
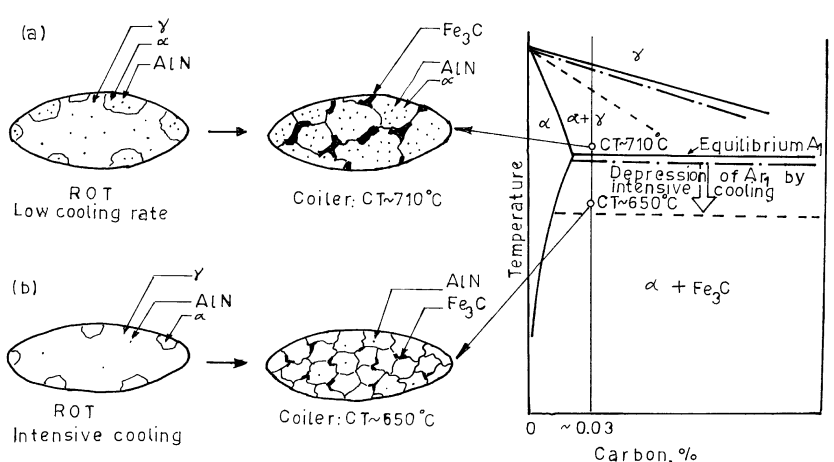

Figure 15. Influence of coiling temperature on structure of hot strip (CT: high). figure 15a. The coarse cementite on grain boundaries in presence of AlN precipitates formed in the hot strip has adverse effect on elongation and $\bar{r}$ values (Pickering 1978). Cementite morphology can be made finer and a part of aluminium and nitrogen can be kept in the solid solution by suppressing $A_{1}$ temperature (figure 15b) through intensive cooling (figure 16) on run-out table (Houdremont 1956). This measure can reduce the coiling temperature of hot strip by $60-80^{\circ} \mathrm{C}$ below the equilibrium $A_{1}$ temperature $\left(721^{\circ} \mathrm{C}\right)$ while still maintaining it in the $\alpha+\gamma$ two-phase region (figure 16) in order to ensure adequate thickness of cementite lamella. This technology will ensure good elongation and $\bar{r}$ values of cold rolled and batch annealed sheet. The typical $\bar{r}$ value of $6 \mathrm{~mm}$

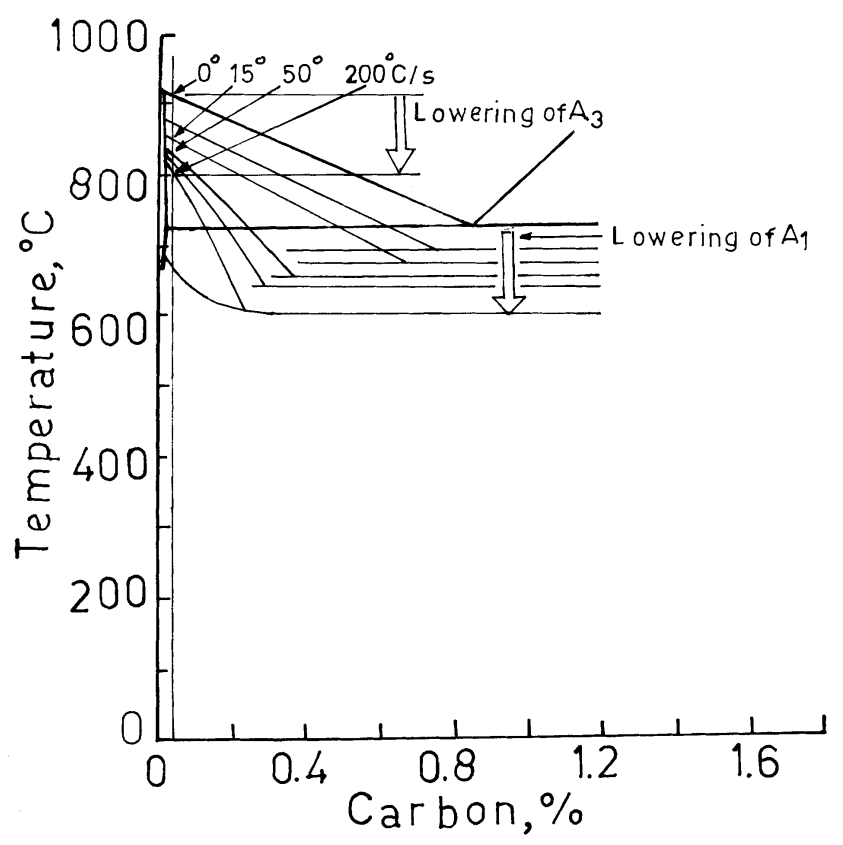

Figure 16. Lowering of $A_{3}$ and $A_{1}$ temperatures with increasing cooling rates.

\section{HOT STRIP MILL}

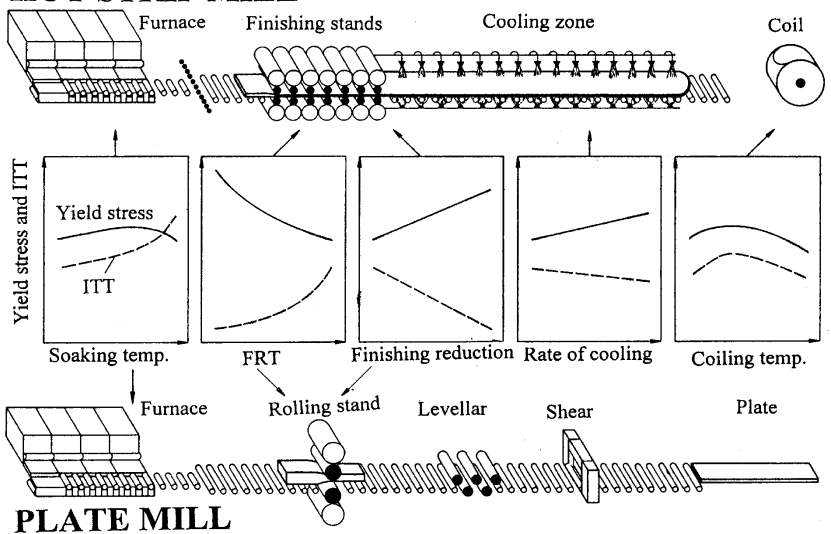

Figure 17. Effect of process parameters on mechanical properties of plate and hot strip. 


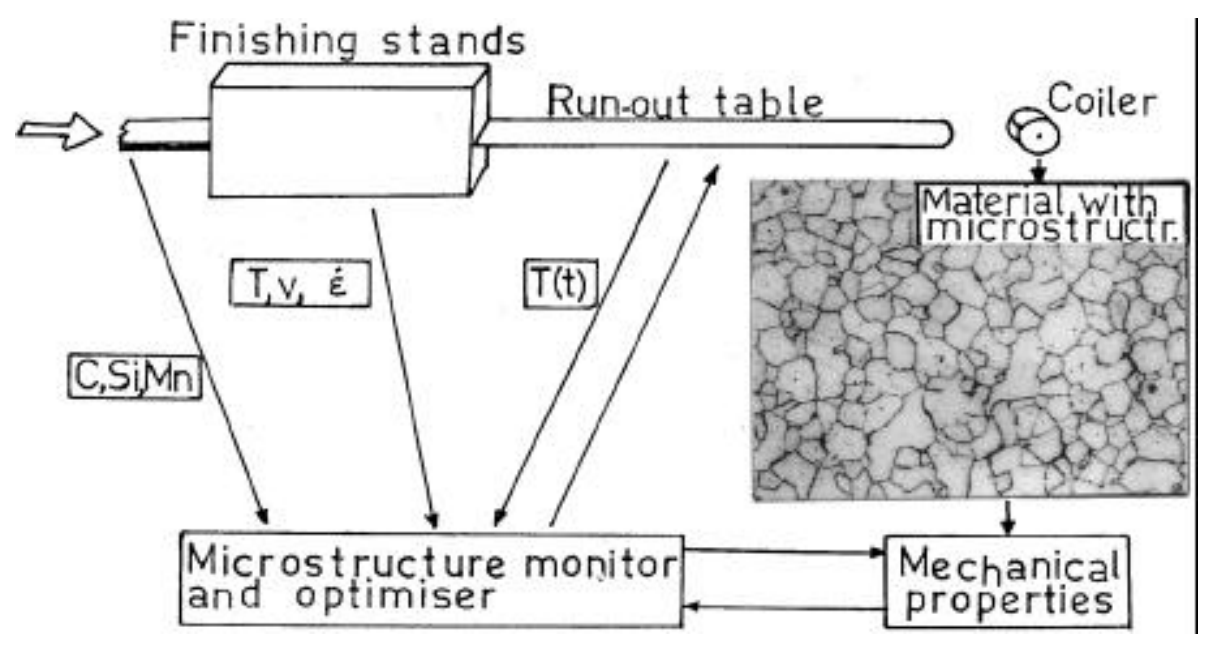

Figure 18. Microstructure-properties management.

thick hot strip (C 0.048, Mn 0.22, P 0.01, N 0.006, $\mathrm{Al} 0.02 \%$; FRT $>\mathrm{Ar}_{3}, \mathrm{CT}: 625^{\circ} \mathrm{C}$ ) cold rolled to $2.7 \mathrm{~mm}$ thickness and batch annealed is 1.40 (Van Cauter et al 2000).

\section{Effect of process parameters on mechanical properties}

Effects of process parameters on mechanical properties of niobium microalloyed plate and strip are shown in figure 17. With increasing reheating temperature of slabs there can be a marginal increase of yield stress (Meyer and deBoer 1977) in a niobium steel up to the dissolution temperature of $\mathrm{Nb}(\mathrm{CN})$. Since some $\mathrm{Nb}(\mathrm{CN})$ precipitates that get dissolved before reaching the solution temperature can reprecipitate and cause precipitation strengthening. After the dissolution temperature is exceeded, excessive austenite grain coarsening can lower the yield strength. The impact transition temperature (ITT) is increased throughout due to precipitation hardening and some grain coarsening.

The lowering of FRT for plate and hot strip increases the strength due to refinement of ferrite grain size which also lowers the ITT. A higher per cent of reduction $(\sim 40 \%)$ at the finishing stage has also the same effect.

On increasing the run-out table cooling rate of hot strip the recrystallization of austenite on run-out table is rendered sluggish leading to a fine ferrite grain size and consequent increase of yield stress and toughness.

The coiling temperature of hot strip is also an important parameter. A too low coiling temperature will lower yield strength due to insufficient precipitation of $\mathrm{Nb}(\mathrm{CN})$ in ferrite decreasing ITT. A too high CT can coarsen the precipitates lowering their strengthening potential and decreasing ITT. For niobium microalloyed steel a coiling temperature of $\sim 690^{\circ} \mathrm{C}$ is found optimum (Militzer et al 1998).

\section{Microstructure-properties management}

Foregoing has reviewed the effects of reheating, finishing, coiling temperatures and drafting schedules on the mechanical properties of plate and hot strip. Recently, the models employed to simulate the thermomechanical processing of steels have been improved to such an extent that the fully empirical ones, based on laboratory and industrial data, are being replaced by those of the knowledge-intensive type, which are rooted in the fundamental principles of mechanical, physical and chemical metallurgy. This development makes it possible for the steel industry to control hot deformation scientifically and produce steel products with tailored microstructures and mechanical properties. This has been shown in figure 18 for hot strip. In this model (Siemens 2000), the actual target values of mechanical properties are pre-set to achieve optimum quality of the rolled products. Using process parameters such as temperature, reduction ratio, strip speed, process time and chemical analyses, the model can ascertain the mechanical properties of the rolled steel.

\section{Conclusions}

The paper addresses various issues of hot processing of low carbon steel plate and hot strip to arrive at optimum structure and properties for specific applications. They are austenite to ferrite transformation, restoration processes, precipitation etc. Today it is possible to practice recrystallization controlled rolling eliminating normalizing treatment of plates in many cases. Introduction of powerful rolling mills has enabled lowering the finish rolling temperature in the two-phase region for much higher strength in finished plate. The drop of mill load associated with phase changes has made the practice of warm rolling for production of hot rolled thin gauge sheets produced so far by cold rolling and annealing, a reality. The coming years 
will demonstrate to what extent production of hot rolled product can be automated through mathematical modelling of deformation processes and to what extent hot rolled products will be able to substitute the heat treatment, cold rolling, annealing operations and the impact that they will have on cost, quality and productivity.

\section{Acknowledgements}

Thanks are due to the management of SAIL for support and to Prof. E G Ramachandran, IIT, Madras; Dr L Meyer, Dr H Baumgardt, Dr W Muschenborn, Thyssen Steel, Duisburg; Dr F Heisterkamp, NPC, Dusseldorf; Dr H Peter, Mannesman Ltd, Duisburg; Prof. H Takechi, Fukuoka Institute of Technology, Fukuoka; Prof. J D Embury, McMaster University, Hamilton; Prof. A J DeArdo, University of Pittsburg; Dr V I Spivakov and Dr V P Kharchevnikov, Tsniichermet, Moscow, for useful discussion.

\section{References}

Barnet M R and Jonas J J 1999 Iron and Steel Inst. Jap. Int. 39 856

Bleck W, Meyer L and Kasper R 1990 Stahl u. Eisen 11026

Borato F, Barbosa R, Yue S and Jonas J J 1988 Proc. thermec'88 (ed.) I Tamura (Tokyo: Iron and Steel Inst.) p. 383

Bramfitt B L and Marder A R 1973 Processing and properties of low carbon steels (NY: AIME) p. 191

Cuddy L J 1985 Encyclopedia of materials science and engineering (Oxford: Pergamon)

DeArdo A J 1984 Conf. high strength low alloy steels (eds) D P Dunne and T Chandra (Wollongong: University of Wollongong) p. 70

Dunne D P, Feng B and Chandra T 1991 Iron and Steel Inst. Jap. Int. $\mathbf{3 1} 1351$

Easterling K 1992 Physical metallurgy of welding (London: Butterworths) p. 122

Frank F C and Stroh A N 1952 Proc. Phys. Soc. B65 811

Ginzburg V 1989 Steel rolling technology (NY: Marcel Dekker Inc.) p. 403

Hansen S S, Vander Sande J B and Cohen M 1980 Met. Trans. A11 387

Harlet P, Becco F, Cantinieaux P, Bouquegneau D, Messien P and Herman J C 1993 Low carbon steel for 90s (eds) R Asfahani and G Tither (Warrendale: Minerals, Metals and Matl. Soc.) p. 389

Hensel A and Lehnert L 1973 Neue Hutte 18654

Hillert M, Nilsson K and Torndahl L E 1971 JISI 20949

Hirsch Y C and Parker B A 1981 Adv. in physical metallurgy and applications of steels (London: Metals Soc.) p. 26

Hoile S 2000 Mater. Sci. Technol. 161079

Houdremont E 1956 Handbook of special steels (Berlin: Springer Verlag)

Inagaki H 1983 Trans. Iron and Steel Inst. Jap. 131059

Jabs S 1995 A review on annealing technology (Brussels: Int. Iron and Steel Inst.) p. 65
Jones J D and Rothwell A B 1968 Deformation under hot working condition (London: Iron and Steel Inst.) p. 78

Kwon O, Lee K J, Kang K B and Lee J K 1998 Asia Steel 205

Lamberigts M and Greday T 1974 Metall. Report CRM 3823

LeBon A and Rofes Vernis J 1976 Conf. controlled processing of HSLA steels (York, UK: University of York) paper no. 6

Lenel U R and Honeycombe R W K 1984 Metal Sci. 18503

McTegart W J and Gattins A 1976 Hot deformation of austenite (ed.) J B Ballance (NY: AIME)

McQueen H J and Jonas J J 1973 Manuf. Engg. Trans. 283

Meyer L and deBoer H 1977 Thyssen Tech. Rep. 920

Meyer L, Buhler H E and Heisterkamp F 1971 Thyssen Res. 38

Militzer M, Poole W J and Sun W 1998 Steel Res. 69279

Ouchi C and Sampei T 1976 Hot deformation of austenite (ed.) J B Ballance (NY: AIME)

Panigrahi B K, Mishra K B, Mediratta S R and Ramaswamy V 1980 Steel India 3258

Panigrahi B K 1981 Unpublished result

Panigrahi B K, Ramaswamy V, Bhan S and Suryanarayana C 1984 New developments on thermomechanical treatment of steels-38th Annual technical meeting (Bangalore: Indian Institute of Metals)

Perry A C, Thompson S W and Speer J G 2000 Iron \& Steel Maker 2747

Pickering F B 1978 Physical metallurgy and design of steel (London: Applied Science Publisher) Chap. 4

Priestner R and de Los Rios E 1976 Heat treatment '76 (London: Metals Soc.) p. 129

Robiller G and Meyer L 1980 RISO conf. metallurgy and materials sci. (ed) N Hansen (Roskilde, Denmark: RISO National Laboratories) p. 311

Siciliano F and Jonas J J 2000 Met. Matl. Trans. A31 511

Siemens A G 2000 AISE Steel Tech. 7791

Smith R P 1953 Acta Met. 1578

Speich G R, Szirmac A and Richards M J 1969 Trans. Met. Soc. 2451063

Speich G R, Davenport V A and Miller R L 1981 Met. Trans. A12 1419

Tamura I, Sekine H, Tanaka T and Ouchi C 1988 Thermomechanical processing of high strength low alloy steel (London: Butterworth) p. 121

Tanaka T 1981 Int. Met. Rev. 26185

Tanaka T 1984 Conf. high strength low alloy steels (eds) D P Dunne and T Chandra (Wollongong: University of Wollongong) p. 6

Tanaka T, Tabata N, Hatomura T and Shiga C 1975 Microalloying '75 (ed) M Korchynsky (NY: Union Carbide) p. 107

Thomson R C and Bhadeshia H K D H 1994 Mater. Sci. Technol. 10193

Thomson R C and Miller M K 1998 Acta Met. 462203

Tomitz A and Kaspar R 2000 Steel Res. 71233

Underwood E 1970 Quantitative stereology (NY: Addison Wesley)

Van Cauter A, Dilewijns J, Horzenberger F, Hubert R A and De Cooman B C 2000 J. Mater. Engg. Perf. 9131

Wilson E G and Gladman T 1988 Int. Met. Rev. 33231

Zidek M, Kubickova B and Raab J 1969 Hutnicke Listy 2498 